\title{
ANALISIS KINERJA ORGANISASI DALAM MEWUJUDKAN PELAYANAN BERKUALITAS KEPADA PENGURUS UNIT KEGIATAN MAHASISWA (UKM) UNIVERSITAS NEGERI MALANG (UM)
}

\author{
Nida Anisatus Sholihah \\ Program Studi Magister Manajemen, Universitas Gajayana Malang \\ E-mail: nida.dedy1986@gmail.com
}

\begin{abstract}
Administrative service is described as one, staff or employee's effort to process and implement everything by determining the method of organizing, building up the organization that suitable with the implementation of policies to accomplish predetermined goals. The objectives of this Study are: (i) to analyze the organizational performance in manifesting the quality of the services toward the Student Activity Unit administrators and; (ii) to analyze what factors support and hinder the performance of UM Student Affairs administrative staff. This study is considered descriptive qualitative research. It is conducted at the Student Affairs Division. The main data source is the Head of Sub Division and administrative staff as and the secondary data source is Student Activity Unit administrators at Universitas Negeri Malang (UM). The data is acquired using interviews, field notes, questionnaires, question lists, and documentation. Meanwhile, the data is analyzed using reduction, presentation of data, and verification or concluding. The result of this study shows that: (i) the quality of the administrative staff or employee at the Student Affairs Division is categorized as good. It matched with the regulation of the Rector of Universitas Negeri Malang. The service toward Student Activity Unit administrators suits to the predetermined SOP, friendly, and corresponds with the predetermined goal; (ii) the factors that support the performance of the Student Affairs Division are the implementation of the Secretarial Workshop for Student organization administrators, the effectiveness of time service, and the speed and accuracy of the Student Activity Unit administrators in making proposals and submitting the accountability of reports funds. While the factors that hinder the performance are the slow pace of Student Activity Unit administrators in making proposals and submitting the accountability of reports funds, lack of understanding of the Student Activity Unit administrators in submitting the project activity proposals, and making the accountability of reports funds.
\end{abstract}

Keywords: performance; administrative services; student activity unit.

Abstrak: Layanan administrasi merupakan usaha seseorang, staf atau pegawai dalam rangka memproses dan melaksanakan segala sesuatu dengan penetapan cara-cara penyelenggaraan pembinaan organisasi sesuai dengan penyelenggaraan kebijakan untuk mencapai tujuan yang telah ditentukan. Tujuan penelitian ini adalah untuk: (i) menganalisis kinerja organisasi dalam mewujudkan pelayanan yang berkualitas kepada pengurus Ormawa Unit Kegiatan Mahasiswa (UKM) dan; (ii) menganalisis faktor-faktor apa saja yang menjadi pendukung dan penghambat kinerja staf administrasi bagian Kemahasiswaan UM. Penelitian ini merupakan jenis penelitian deskriptif kualitatif yang dilaksanakan di Bagian Kemahasiswaan Universitas Negeri Malang (UM) dengan sumber data primer Kasubag dan Staf administrasi Subbag MPIKA UM dan sumber data sekunder yaitu pengurus UKM di UM. Data diperoleh dengan cara wawancara, catatan lapangan, penyebaran kuesioner dan daftar pertanyaan, dan dokumentasi. Sedangkan analisis data dilakukan dengan cara reduksi, penyajian data, dan verifikasi atau penarikan kesimpulan. Hasil penelitian menunjukkan bahwa: (i) kinerja staf administrasi atau pegawai di bagian Kemahasiswaan UM termasuk kategori baik dan berkualitas karena sesuai dengan peraturan Rektor UM. Pelayanan kepada pengurus UKM telah sesuai dengan SOP yang telah ditetapkan, ramah, dan sesuai dengan target yang telah ditetapkan; (ii) faktor-faktor yang menjadi pendukung kinerja Kemahasiswaan adalah penyelenggaraan kegiatan Workshop Kesekretariatan bagi pengurus Ormawa, waktu 


\begin{abstract}
pelayanan yang efektif, serta kecepatan dan ketepatan pengurus UKM dalam membuat proposal kegaitan dan penyerahan laporan pertanggungjawaban dana. Sedangkan faktor penghambatnya adalah lambatnya pengurus UKM dalam pembuatan proposal kegaitan dan penyerahan laporan pertanggungjawaban dana, tidak pahamnya pengurus UKM dalam pengajuan proposal kegiatan dan pembuatan laporan pertanggungjawaban dana.
\end{abstract}

Kata kunci: kinerja; layanan administrasi; unit kegiatan mahasiswa.

Pelayanan administrasi merupakan bagian terpenting bagi Orgnasisasi Kemahasiswaan Unit Kegiatan Mahasiswa (UKM). Apabila akan melaksanakan kegiatan, pengurus UKM harus mengikuti prosedur administrasi yang telah ditentukan oleh Universitas Negeri Malang (UM).

Fenomena yang terjadi, banyak pengurus UKM yang mengalami kesulitan terhadap pelayanan administrasi. Hal ini dibuktikan dengan adanya program kerja yang tidak terlaksana dikarenakan pengurusan administrasi yang kurang baik. Selain itu, dana program kegiatan juga tidak dapat diberikan. Disamping itu, keterlambatan pelayanan administrasi yang dilakukan oleh staf administrasi bagian keuangan MPIKA juga sering menjadi kendala tidak terlaksananya program kerja UKM. Dari hasil observasi peneliti di Bagian Kemahasiswaan UM, penyebab terhjadinya hal-hal tersebut adalah: (1) kurangnya sosialisasi dari pimpinan dan staf administrasi Bagian Kemahasiswaan UM tentang prosedur administrasi UKM dikarenakan tupoksi pegawai di Bagian Kemahasiswaan UM jumlahnya sangat banyak yakni terdapat 150 kegiatan dalam berbagai bidang; (2) pengurus Ormawa tidak memahami dan tidak dapat mengikuti prosedur pengajuan laporan pertanggungjawaban dengan benar.

Berdasarkan permasalahan tersebut, peran sumber daya manusia yang berkualitas sangat dalam melaksanakan tugas-tugasnya. Panggabean (2004) menyatakan bahwa dalam sebuah organisasi, SDM memiliki peranan yang sangat penting yakni dapat menentukan dinamika iklim organisasi dan juga sebagai asset organisasi dan pengelola aset. Faktor individu dan organisasi berpengaruh terhadap kinerja pegawai, disinilah pentingnya manajemen SDM berperan, terutama pada pengaturan efektif dan efisiensinya suatu hal dalam organisasi dalam rangka mencapai tujuan organisasi yang telah ditetapkan.

Menurut Dewi (2019:113), menyatakan bahwa kinerja adalah suatu capaian kerja seseorang dalam mengemban tugas dan tanggung jawab yang diberikan kepadanya dengan waktu yang telah ditentukan yang mampu diselesaikan dengan usaha terbaiknya dan dapat mewujudkan tujuan organisasi. Dalam penelitian ini menggunakan teori pemasaran jasa sebagai acuan terutama yang berkaitan dengan kualitas pelayanan dan kepuasan pelanggan. Berikut ini adalah pendapat Fatkurroji (2015:73) tentang pemasaran jasa Pendidikan: Pemasaran jasa pendidikan adalah suatu cara atau kegiatan yang dilakukan oleh lembaga atau instansi yang bergerak dalam bidang pendidikan untuk mempertahankan, mengembangkan, dan mendapatkan keuntungan. Supaya memiliki reputasi yang baik di mata konsumen, instansi tersebut harus berupaya untuk memberikan pelayanan yang terbaik agar konsumen memperoleh kepuasan. Hal-hal yang perlu diperhatikan dan dilakukan oleh instansi atau lembaga pendidikan yaitu mengidentifikasi dan mengenali kebutuhan konsumen yang harus dipuaskan, menetapkan produk yang akan diproduksi, menetapkan harga produk yang tepat, menetapkan cara promosinya, dan mengatur proses memproduksinya.

Menurut Arbangi, Dakir, dan Umiarso (2016:18-19), marketing pendidikan mempunyai beberapa konsep dasar, diantaranya: (1) kebutuhan dan keinginan konsumen dijadikan sebagai dasar tujuan bisnis sejak awal, dan (2) kebutuhan dan keinginan konsumen dikembangkan melalui pendekatan organisasi. Selain itu, disebutkan pandangan tentang lembaga pendidikan sebagai organisasi produksi sebagai berikut: Lembaga pendidikan merupakan suatu organisasi yang berperan dalam bidang pendidikan dan memberikan jasa bidang pendidikan kepada konsumen. Oleh karena itu kualitas atau kompetensi merupakan hal mutlak yang harus terus menerus ditingkatkan. Peningkatan kualitas ini diwujudkan dengan dua tahap, yaitu pekerjaan yang menghasilkan interelasi dan kegiatan yang menghasilkan output. Proses tersebut bertujuan untuk meningkatkan kualitas pendidikan secara berkelanjutan dan terpadu. Namun upaya peningkatan kualitas tersebut tidak dapat dicapai secara instan, akan tetapi bertahap pada setiap komponen pendidikan. 
Kualitas layanan adalah alat ukur yang digunakan untuk mengetahui dampak pada keberlanjutan program kerja UKM. Kualitas Layanan merupakan penilaian seseorang atau publik terhadap segala sesuatu yang diberikan seseorang atau instansi terhadap customer atau pelanggan. Hal ini sesuai dengan paparan Falla (2013: 450) yang menyebutkan bahwa "kualitas layanan adalah penilaian dari konsumen terhadap pelayanan yang diterima dengan diharapkan". Hal yang sama juga disampaikan oleh Panjaitan (2016: 270) bahwa "kualitas pelayanan adalah cara untuk memenuhi kebutuhan dan keinginan konsumen dan ketepatan penyampaiannya dalam mewujudkan harapan konsumen. Sedangkan Robia (2020:89) menyebutkan bahwa "kualitas layanan merupakan suatu kegiatan yang dilakukan oleh perusahaan jasa untuk memenuhi keinginan konsumen dan membuat konsumen merasa puas terhadap pelayanan tersebut yakni dengan cara memberikan atau menyampaikan jasa yang melebihi dari apa yang diharapkan konsumen". Menurutnya, faktor dominan yang mempengaruhi kualitas layanan yaitu motivasi kerja birokrasi dan aparatur, kemampuan, pengawasan, perilaku, komunikasi, disposisi, struktur, aliran informasi, dan restrukturisasi organisasi.

Menurut Tjiptono dalam Robiah (2020:89) untuk mengevaluasi kualitas jasa yang dapat menentukan pelayanan publik yang berkualitas, yaitu 1) Tangible (Nyata) yaitu adanya kepedulian serta perhatian dari penyedia jasa kepada konsumen secara nyata; Reliability (Keandalan) yaitu kemampuan sebuah perusahaan dalam memberikan jasa secara tepat waktu sesuai dengan yang dijanjikan; Responsiveness yaitu pemberian pelayanan dengan cepat dan tanggap yang dilakukan langsung oleh karyawan suatu perusahaan; Assurance (Jaminan) karyawan harus memiliki pengetahuan dan memiliki perilaku yang baik untuk dapat membangun kepercayaan pelanggan dalam menggunakan jasa suatu perusahaan, dan Empathy (empati) bentuk perhatian dan kepekaan terhadap kebutuhan konsumen dari seorang karyawan secara individu. Sedangkan kepuasan konsumen menurut Krisdianto, Haryono, dan Gagah dalam Rabiah (2020:90) suatu perasaan konsumen atau pelanggan baik itu senang ataupun kecewa terhadap pelayanan atau produk yang diberikan oleh perusahaan dan perbandingan antara kinerja karyawan dengan keinginan konsumen.

Kinerja karyawan sangat mempengaruhi tujuan yang ingin dicapai oleh instansi. Oleh sebab itu, setiap perusahaan perlu melakukan penilaian atau evaluasi kinerja pegawainya. Robbins (2006) menyatakan 3 kriteria yang digunakan untuk mengukur kinerja: (1) kualitas kerja yaitu standart yang baik yang harus dimiliki oleh seorang karyawan dalam melaksanakan pekerjaannya; (2) kuantitas kerja adalah banyaknya pekerjaan seorang karyawan dalam waktu yang telah ditentukan; (3) sikap kerja merupakan tindakan dan kewajiban yang harus dilaksanakan oleh karyawan dalam mengemban tugas dan tanggung jawabnya. Secara teoritis, suatu organisasi akan sukses dan mencapai kinerja apabila dapat memberikan motivasi kepada individu sehingga menumbuhkan kreativitas dan inisiatif. Kinerja pegawai banyak didukung oleh gabungan kemampuan kepemimpinan, motivasi, dan kepuasan.

Penelitian yang dilakukan oleh Triyanto (2017) menyimpulkan bahwa Kinerja BPPT dalam mewujudkan pelayanan prima terhadap masyarakat di Kota Semarang sudah cukup baik karena ketiga dimensi kinerja dan kualitas layanan sudah diterapkan dengan baik, yakni produktivitas, responsibilitas, dan akuntabilitas. Sedangkan dimensi responsivitas masih terkendala pada informasi pelayanan yang kurang jelas karna website BPPT belum maksimal sehingga belum bisa digunakan oleh masyarakat. Dimensi kualitas layanan belum diterapkan dengan baik karena dari hasil pelayanan perizinan terkadang tidak tepat waktu atau melebihi ketentuan SOP dan memerlukan proses panjang, sehingga kemudahan pelayanan yang diberikan dianggap belum baik.

Selain itu, penelitian yang dilakukan oleh Ariany dan Putera (2013) menyimpulkan bahwa: (1) kinerja pelayanan KP2TPM kota Pariaman termasuk cukup baik terutama dari segi administratif; (2) secara administrasi dan teknik pelayanan perizinan yang dilakukan oleh aparatur KP2TPM kota Pariaman telah mengarah pada pelayanan yang berkualitas. Hal ini karena individu-individu atau karyawan telah melaksanakan tugas sesuai dengan teori yang telah dikemukakan di atas.

Sari (2016) yang melakukan penelitian tentang Peningkatan Kinerja Pegawai Melalui Kepuasan Kerja dan Disiplin Kerja dengan variabel kepuasan dan ketepatan waktu atau disiplin kerja dan alat regresi sederhana dan teknik analisis berganda, menemukan bahwa adanya pengaruh yang kuat antara 
kepuasan terhadap kinerja pegawai, adanya pengaruh yang kuat antara kedisiplinan terhadap kinerja pegawai, dan adanya pengaruh kepuasan dan disiplin kerja terhadap kinerja pegawai, baik secara simultan maupun parsial. Kepuasan kerja dan disiplin kerja merupakan dua faktor yang berpengaruh terhadap kinerja. Wididana (2017) berdasarkan hasil penelitiannya menyimpulkan kualitas pelayanan berpengaruh baik dan signifikan terhadap kepuasan pasien, kualitas pelayanan berpengaruh baik dan signifikan terhadap kepercayaan pasien, dan kepuasan pasien berpengaruh baik dan signifikan terhadap kepercayaan pasien Rumah Sakit Umum Santi Graha. Artikel ini bertujuan untuk mengungkap kinerja organisasi dalam mewujudkan pelayanan berkualitas kepada pengurus Unit Kegiatan Mahasiswa (UKM) Universitas Negeri Malang (UM).

\section{METODE}

Dalam penelitian ini menggunakan pendekatan kualitatif sedangkan jenis penelitian studi kasus, dan teknik analisis data yang digunakan adalah analisis deskriptif kualitatif yaitu menganalisis data dari observasi dan wawancara yang diperoleh kemudian dikomparasikan dengan teori-teori yang relevan dengan masalah yang diteliti. Teknik pengumpulan data dalam penelitian ini adalah wawancara, observasi, dan dokumentasi, sedangkan instrumen yang digunakan adalah angket dan kuesioner. Pengumpulan data adalah prosedur untuk memperoleh data yang diperlukan secara sistematik dan standar. Dalam usaha mengumpulkan data, peneliti berusaha mencari informasi-informasi yang berkaitan dengan fokus dalam penelitian, baik berupa fakta-fakta maupun dokumentasi. Teknik observasi yaitu pengamatan dan pencatatan secara sistematik terhadap gejala yang tampak pada objek penelitian. Selain pedoman observasi, peneliti menggunakan alat pendukung, antara lain: (1) buku catatan, (2) foto-foto, (3) berkasberkas data UKM. Dalam pelaksanaannya, yang menjadi sorotan peneliti adalah data-data yang ada hubungannya dengan fokus penelitian, yaitu proses konsultasi pengurus UKM dengan Kasubag atau staf administrasi di bagaian Kemahasiswaan, arsip jumlah dana UKM selama 3 tahun tereakhir, keadaan gedung UKM, keadaan ruang sekretariat UKM, dan keadaan sarana dan prasarana di UKM. Adapun wawancara yang dilakukan dalam penelitian ini adalah dengan mengajukan pertanyaan yang mengarah pada kedalaman informasi dan dilakukan tidak secara formal terstruktur. Dokumentasi dalam penelitian ini yaitu dengan melihat dokumen-dokumen resmi seperti peraturan-peraturan, Surat Keputusan Rektor UM, buku-buku catatan, dan berkas-berkas arsip laporan pertanggung jawaban kegiatan. Data-data tersebut yaitu program kerja, susunan kepengurusan, laporan penggunaan dana, dan lain-lain.

Adapun tahapan analisis data dalam penelitian ini sebagai berikut: (1) Observasi di Bagian Kemahasiswaan yang meliputi bentuk pelayanan staf administrasi di Bagian Kemahasiswaan dan pengamatan kegiatan pengurus UKM. Hasil observasi tersebut ditulis oleh peneliti kemudian digunakan sebagai catatan lapangan untuk mendukung validitas penelitian. Pada saat observasi, dokumentasi juga menjadi bagian penting untuk mendapatkan hasil penelitian yang valid. Dokumentasi tersebut berupa foto-foto saat staf administrasi melakukan pelayanan terhadap mahasiswa pengurus UKM. Selain itu, berbagai data atau arsip UKM yang menjadi pendukung penelitian ini juga dianalisis, misalnya daftar penggunaan dana UKM selama tiga tahun terakhir, struktur organisasi Kemahasiswaan di UM, daftar nama serta tugas dan fungsi jabatan pada setiap staf administrasi di Bagian Kemahasiswaan UM, dan alur prosedur pengajuan proposal kegiatan UKM. (2) Peneliti membuat angket dan kuesioner untuk dibagikan kepada staf administrasi di Bagian Kemahasiswaan dan kepada mahasiswa pengurus UKM. Jawaban-jawaban dari angket dan kuesioner tersebut dikumpulkan, ditulis, dipahami, dan dianalisis guna sebagai bahan dalam menarik hasil penelitian dan kesimpulan.

\section{HASIL}

Berdasarkan hasil kuesioner yang disebar kepada 34 pengurus UKM, sebanyak 20 pengurus UKM yang menyatakan "sangat baik" terhadap keramahan, ketepatan waktu, dan kecepatan pelayanan pegawai Subbag MPIKA. Sebanyak 10 orang yang menyatakan "baik" dan 4 orang menyatakan "kurang baik". Hal ini berarti mahasiswa merasa puas dengan pelayanan pegawai di Subbag MPIKA UM. Hal ini juga 
menunjukkan bahwa pelayanan staf administrasi di bagian Kemahasiswaan UM termasuk kategori baik karna hasil kuesioner yang mayoritas merespon positif. Berikut adalah grafik hasil kuesioner kepada UKM

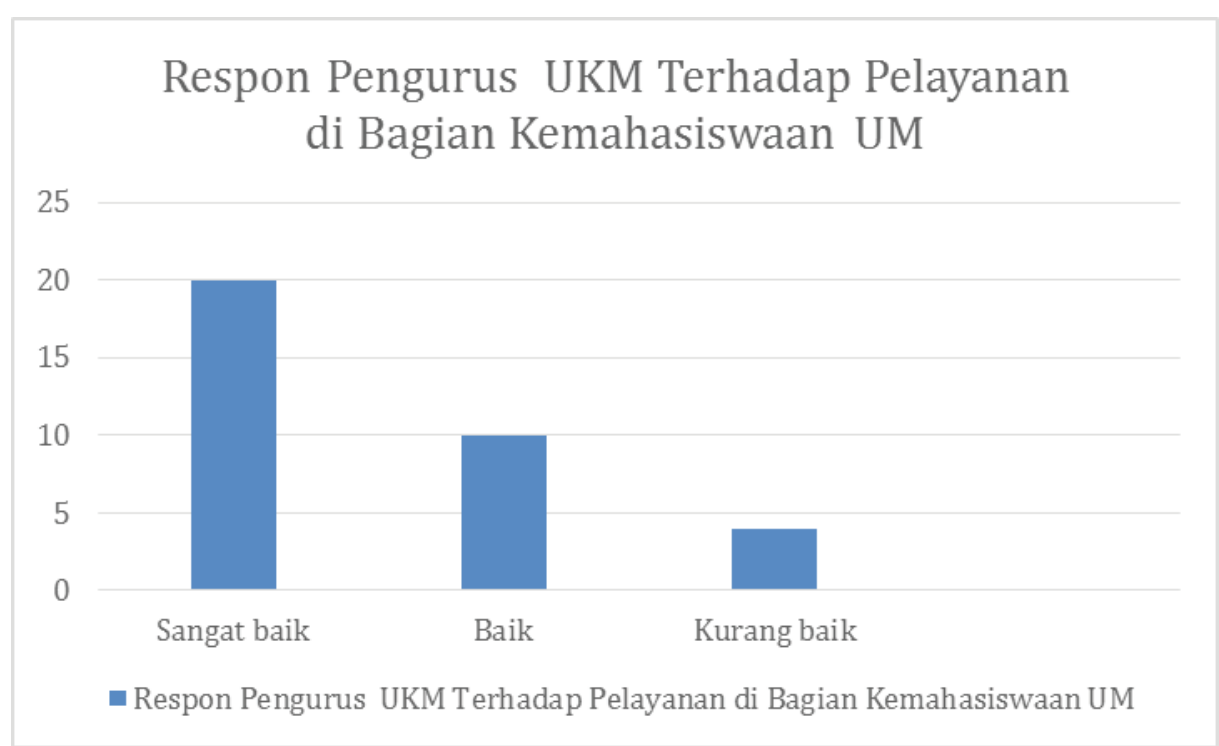

Sedangkan kuesioner yang disebar kepada pegawai atau staf administrasi di Subbag MPIKA, dari 9 pegawai 7 pegawai menyatakan bahwa setelah diberikan materi dalam Workshop Kesekretaiatan Ormawa, pengurus Ormawa lebih disiplin dalam menyerahkan laporan pertanggungjawaban dan lebih cepat dalam pemrosesan surat menyurat untuk pelaksanaan kegiatan. Hal ini dapat disimpulkan bahwa kinerja pengurus Ormawa meningkat dan lebih baik setelah diberikan materi Workshop Kesekretariatan dan pelayanan yang berkualitas dari pegawai.

\section{Produktivitas}

Ukuran produktivitas dalam penelitian ini adalah mengukur tingkat pelayanan publik terhadap hasil yang diharapkan. Pelayanan di Bagian Kemahasiswaan menggunakan standar biaya yang ditetapkan dalam peraturan Rektor UM untuk masing-masing UKM. Selain itu, ada SOP pengajuan proposal bagi UKM dan prosedur pelayanan bagi UKM.

\section{Kualitas Pelayanan}

Dalam mencapai pelayanan yang berkualitas sesuai yang telah ditetapkan dan ditargetkan perlu dukungan dari berbagai pihak, yakni adanya sarana dan prasarana yang mendukung, misalnya gedung kegiatan atau atau gedung pertunjukan yang relevan, penyediaan ATK sesuai kebutuhan, kondisi secretariat UKM yang baik, misalnya adanya fentilasi udara, tersedianya tempat sampah, dan taman yang baik, dan lain-lain.

Dari beberapa pernyataan hasil wawancara dengan mahasiswa pengurus UKM didapatkan hasil bahwa pelayanan dari pegawai di Bagian Kemahasiswaan telah baik dan berkualitas, baik konsultasi proposal, laporan keuangan, pengajuan surat izin kegiatan, pengajuan Surat Tugas untuk pemateri, pengajuan surat pinjam gedung pertemuan atau gedung pertunjukan, surat peminjaman alat misal laptop, LCD, kamera SLR, dan lain-lain, maupun surat balasan atau pemenuhan kebutuhan dari surat-surat terebut diperoleh dengan cepat sesuai waktu yang diharapkan oleh pengurus UKM.

\section{Responsivitas}

Berdasarkan hasil wawancara tersebut mahasiswa mengaku ada beberapa kekurangan yakni kurangnya sosialisasi tentang prosedur administrasi dagi UKM, dikarenakan tupoksi pegawai di Bagian Kemahasiswaan UM jumlahnya sangat banyak yakni terdapat 150 kegiatan dalam berbagai bidang. Selain itu kadangkala pegawai tidak ada di tempat. Pegawai sedang tugas dinas di luar kota, sedang rapat, dan lain-lain. Hal tersebut merupakan kendala bagi mahasiswa karna waktu bertemu untuk pengambilan jawaban surat permohonan, misal Surat Keputusan, Surat Tugas, sertifikat peserta dan 
pemateri kegiatan, serta pengambilan dana kegiatan kadangkala mundur dan tidak sesuai dengan waktu yang diprediksi.

\section{Responsibilitas}

Ada beberapa peraturan Rektor yang digunakan sebagai acuan dalam penelitian ini, diantaranya Kode Etik Staf Administrasi dan Peraturan Rektor tentang Ormawa. Dari penilaian lapangan, kinerja pegawai di Bagian Kemahasiswaan sudah sesuai dengan hal-hal yang telah ditetapkan dalam peraturan rektor tersebut. Hal ini mengindikasikan bahwa kinerja pegawai telah baik.

\section{Akuntabilitas}

Hasil pengamatan dan wawancara didapatkan bahwa pelayanan administrasi dan teknik pelayanan yang dilakukan oleh pegawai di Bagian Kemahasiswaan termasuk kategori baik dan berkualitas. Walaupun masih terdapat kendala bagi mahasiswa yaitu minimnya sosialisasi dan kesulitan waktu untuk menemui pegawai.

Hasil penelitian ini selaras dengan konsep dasar marketing pendidikan pendidikan yang dikemukakan oleh Arbangi, Dakir, dan Umiarso yakni dalam mengembangkan organisasi dilakukan pendekatan untuk memuaskan kebutuhan dan keinginan konsumen. Dalam hal ini, bagian Kemahasiswaan UM telah melakukan pendekatan tersebut dengan cara menyelenggarakan kegiatan Workshop bagi Pengurus Ormawa UKM di UM dengan materi-materi yang diberikan sesuai dengan kebutuhan dan keinginan pengurus UKM. Selain itu, juga dipaparkan bawa tujuan utama proses peningkatan kualitas adalah untuk meningkatkan mutu pendidikan secara berkelanjutan, terus menerus, dan terpadu. Hal ini juga sesuai dengan hasil penelitian ini, yakni pelayanan pegawai di Bagian Kemahasiswaan UM juga dilakukan secara terus menerus dan berkelanjutan yang mengindikasikan pada pelayanan yang baik dan berkualitas, karena pegawai Bagian Kemahasiswaan UM secara kontinyu memberikan waktu luangnya untuk melayani konsultasi pengurus UKM yang akan mengajukan proposal ataupun mengurus pencairan dana atau laporan pertanggungjawaban dana kegiatan.

Hal-hal yang menjadi faktor pendukung staf administrasi Bagian Kemahasiswan UM dalam mewujudkan pelayanan yang berkualitas kepada pengurus UKM di UM adalah (1) dosen pembimbing UKM yang memiliki keahlian pada masing-masing bidang dalam membimbing dan membina pengurus dan anggota UKM dalam menyelenggarakan berbagai kegiatan; (2) tenaga kependidikan yang cakap dalam ilmu administrasi dan loyal dalam pelayanan; (3) tersedianya sarana dan prasarana yang baik dan memadai. UM menyediakan gedung terpadu sebagai ruang sekretariat untuk masing-masing UKM agar pengurus UKM dapat saling berkoordinasi, berinteraksi dalam membuat program kerja, menyiapkan kegiatan, dan pelaporan kegiiatan; (4) mahasiswa pengurus dan anggota UKM yang terseleksi dan mendapat prestasi pada masing-masing bidang minat dan kegemaran.

Sedangkan faktor penghambat staf administrasi bagian Kemahasiswan UM dalam mewujudkan pelayanan yang berkualitas kepada pengurus UKM di UM adalah (1) prosedur pengajuan proposal kegiatan yang panjang dan harus melalui beberapa tahap; (2) banyaknya bukti pengeluaran dana kegiatan UKM yang harus diserahkan lengkap berserta uraian laporannya dalam waktu yang terbatas; (3) tidak sesuainya waktu yang telah ditentukan dalam SOP Bagian Kemahasiswa yakni 1 (satu hari) dalam memverifikasi dan mendisposisi proposal UKM dengan kenyataan yakni diselesaikan dalam 2-3 hari; (4) banyaknya jumlah kegiatan mahasiswa di Bagian Kemahasiswaan UM dalam berbagai bidang dalam waktu yang relatif bersamaan; (5) kurangnya tenaga kependidikan yang ditugaskan di bagian Kemahasiswaan UM, hal ini tidak relevan dengan banyaknya kegiatan yang harus diselenggarakan.

Dari beberapa faktor pendukung tersebut akan menjadi kekuatan bagi UM dalam meningkatkan kualitas dan mengembangkan berbagai kegiatan dalam berbagai kegiatan bidang minat dan kegemaran. Sedangkan beberapa faktor penghambat tersebut akan menjadi bahan evaluasi dalam peningkatan kinerja dan kualitas pelayanan di Bagian Kemahasiswaan UM. Berikut adalah bagan struktur dan fungsi pengurus UKM. 


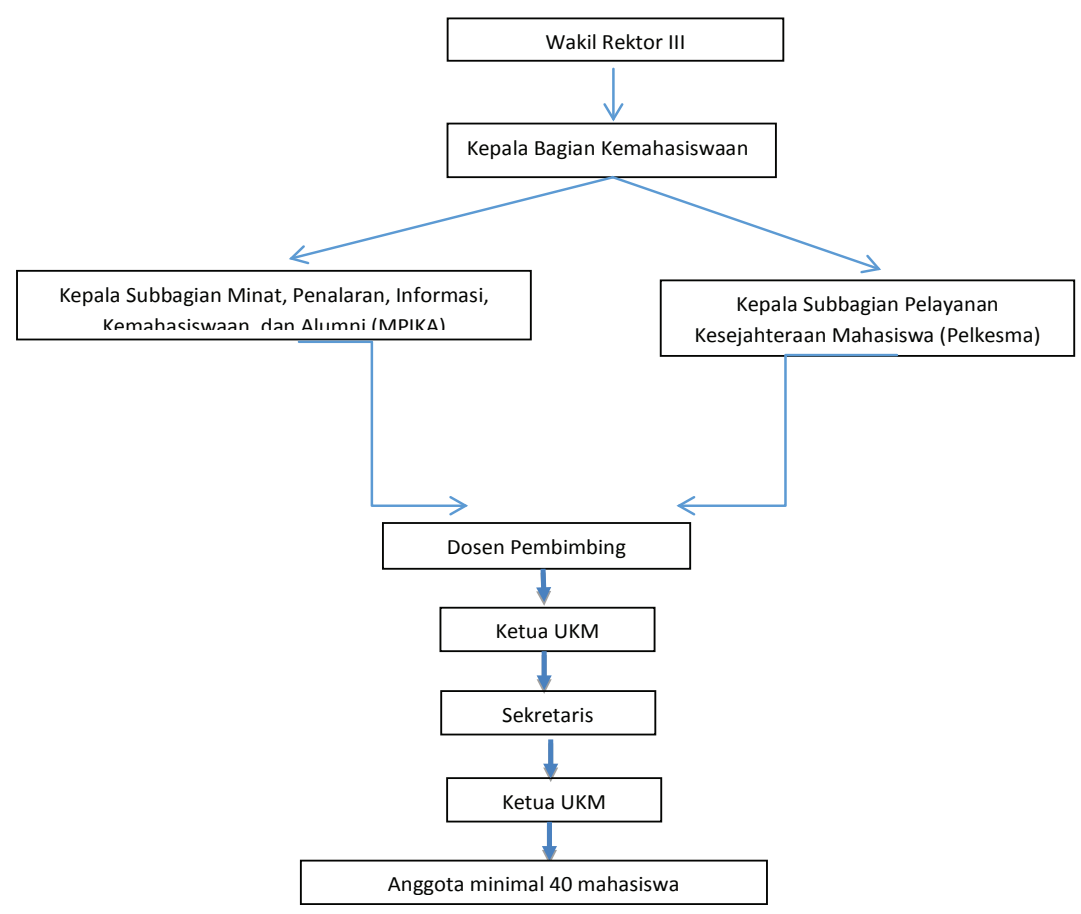

Gambar 1 diilustrasikan struktur organisasi Kemahasiswaan UM berdasarkan Peraturan Rektor Nomor 13/KEP/ UN32/KM/2012 tentang Pedoman Organisasi Kemahasiswaan.

Dalam Peraturan Rektor Nomor 27 tahun 2018 tentang Kode Etik Tenaga Kependidikan Universitas Negeri Malang, tenaga kependidikan atau pegawai UM harus memiliki kode etik sebagai berikut: melaksanakan tugas ketentuan; membangun etos kerja dalam rangka meningkatkan kinerja Organisasi; dan berorientasi pada usaha dalam meningkatkan kualitas kerja. Adapun kewajiban pegawai yang diatur dalam peraturan tersebut diantaranya adalah memberikan pelayanan terbaik kepada masyarakat dalam hal ini mahasiswa, menyelesaikan sebaik-baiknya semua laporan yang diterima tentang pelanggaran disiplin. Selain itu, setiap pegawai bertanggung jawab untuk memenuhi tuntutan atas penerapan standar professional pendidikan; memberikan dorongan yang baik kepada sesama tenaga kependidikan untuk meningkatkan profesionalisme pelayanan terhadap mahasiswa; dan melaksanakan tugas sesuai rencana kerja atau target yang telah disepakati. Namun, fakta menunjukkan bahwa pelayanan oleh tenaga kependidikan tidak sesuai dengan target yang telah ditentukan, yakni terjadinya serapan dana Ormawa yang kurang baik pada waktu yang telah ditentukan.

Dari hasil observasi, peneliti menemukan adanya pengurus UKM yang belum memahami prosedur dalam pengajuan proposal kegiatan dan pelaporan dana kegiatan. Hal ini yang mempersulit staf administrasi dalam melakukan pelayanan. Akan tetapi, para staf administrasi seringkali meluangkan waktunya untuk memberikan arahan tentang cara-cara dan prosedur yang tepat dalam pelaporan dana kegiatan UKM dengan ramah. Dari hasil konsultasi tersebut, mahasiswa pengurus UKM menjadi paham dan mengikuti langkah-langkah yag telah ditetapkan oleh institusi.

Selain itu, untuk memberikan pemahaman pengurus UKM tentang pengjuan proposal kegiatan, surat izin kegiatan, peminjaman tempat, dan pengajuan dan pelaporan dana kegiatan, Bagian Kemahasiswaan UM menyelenggaran workshop administrasi bagi pengurus Ormawa UM. Adapun materi-materi yang diberikan saat workshop adalah Pengarahan dan materi tentang program oleh Wakil Rektor III Materi Administrasi Kesekretariatan Ormawa oleh Kabag Kemahasiswaan Birokrasi UM oleh Kasubbag MPIKA Keuangan oleh Kabag Keuangan Informasi Sarana Prasarana UM oleh Kabag UHTBMN

Setelah pengurus UKM memahami langkah-langkah dan prosedur pengajuan proposal kegiatan dan cara pelaporan dana kegiatan, layanan administrasi berjalan lancar, cepat dan mudah. Para staf administrasi dengan cekatan dapat mencairkan dana kegiatan kepada pengurus UKM karena bukti-bukti pengeluaran anggaran sudah lengkap dan dapat dipertanggungjawabkan. 
Prosedur layanan administrasi di Universitas Negeri Malang (UM) bagi pelaksanaan kegiatan UKM dilakukan dengan tahap berikut. Pertama UKM mengajukan proposal kegiatan yang memuat nama kegiatan, tempat, sasaran, alasan diadakan kegiatan, dan total anggaran yang diperlukan dalam pelaksanaan kegiatan tersebut. Kedua, pimpinan Bidang Kemahasiswaan menyetujui kegiatan dan dana dapat diberikan. Ketiga, setelah kegiatan dilaksanakan, pengurus UKM harus membuat laporan pertanggungjawaban kegiatan dengan mengikuti prosedur laporan yang telah ditentukan, yakni menyerahkan bukti-bukti pengeluaran dana pelaksanaan kegiatan tersebut. Berikut alur pengajuan proposal dana kegiatan UKM di UM.

\begin{tabular}{|c|c|}
\hline UKM & Pengajuan proposal minimum 3 Minggu sebelum hari-H $\rightarrow$ Proposal dan Ringkasan \\
\hline Subbag TU & Menerima dan mengagendakan usulan ke dalam sistem aplikasi e-office \\
\hline Staf Wakil Rektor III & Menerima surat, mengagendakan ke sistem aplikasi dan meneruskan ke WR III \\
\hline & $\checkmark$ \\
\hline Wakil Rektor III & Mempelajari, memverifikasi dan mendisposisikan \\
\hline Staf Wakil Rektor III & Mendistribusikan proposal sesuai isi disposisi \\
\hline Kabag Kemahasiswaa & Mengagendakan, meneliti dan meneruskan proposal ke Kabag Kemahasiswaan \\
\hline & 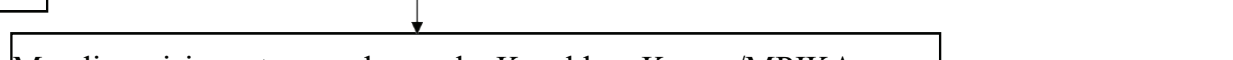 \\
\hline Kasubbag MPIKA & Mendisposisi surat permohonan ke Kasubbag Kesma/MPIKA \\
\hline Kasubbag MPIKA & Medisposisi surat permohonan ke staf PUMK untuk memferivikasi dan merasionalisasi \\
\hline Staf PUMK & Menerima, mengagendakan dan memberikan form lembar persetujuan dana kegiatan \\
\hline Kasubbag MPIKA & Mempelajari usulan dan memberikan acc besaran dana yang disetujui \\
\hline & 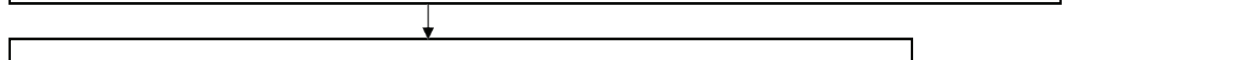 \\
\hline Staf PUMK & $\begin{array}{l}\text { Menerima proposal yang sudah ditentukan besaran dananya, } \\
\text { mengagenda dan menyampaikan kepada UKM terkait }\end{array}$ \\
\hline Staf PUMK & Merekap dan mengusulkan dana proposal ke Bagian Keuangan \\
\hline Staf PUMK & Memproses pencairan dana kegiatan \\
\hline & $\checkmark$ \\
\hline Staf PUMK & Menerima pencairan dana kegiatan untuk diteruskan kepada UKM \\
\hline
\end{tabular}

Gambar 2 diilustrasikan prosedur alur pengajuan proposal dana kegiatan berdasarkan Peraturan Kepala Bagian Kemahasiswaan UM.

\section{PEMBAHASAN}

Dwiyanto (2002) mengemukakan beberapa indikator untuk mengukur kinerja birokrasi pelayanan publik, yaitu: (1) produksitivitas yang meliputi tingkat efektivitas pelayanan dan efisiensi. Produktivitas mencakup rasio input dan output; (2) kualitas layanan, hal ini terkait dengan kepuasan masyarakat dalam hal ini mahasiswa pengurus UKM; (3) responsivitas merupakan kemampuan organisasi publik dalam menjalankan misi dan tujuannya, yakni memenuhi kebutuhan masyarakat; (4) responsibilitas yakni ukuran pelayanan organisasi publik sesuai dengan prinsip-prinsip manajemen dan administrasi yang benar serta sesuai dengan kebijakan organisasi dan peraturan-peraturan organisasi; (5) akuntabilitas yakni standar 
ukuran kebijakan dan kegiatan organisasi publik konsisten dengan kehendak konsumen atau masyarakat.

Dari hasil riset artikel Triyanto (2017) pada Jurnal Penelitian Sosial dan Politik Volume 6, No. 4 didapatkan hasil yang serupa dengan penelitian ini, yakni kinerja Badan Pelayanan Perizinan Terpadu (BPPT) kota Semarang dalam mewujudkan pelayanan berkualitas terhadap masyarakat di Kota Semarang sudah cukup baik karena tiga dimensi kinerja dan kualitas layanan yakni produktivitas, responsibilitas, dan akuntabilitas sudah diterapkan dengan baik. Sedangkan dimensi responsivitas masih terkendala pada informasi pelayanan yang kurang jelas dan website BPPT yang belum optimal sehingga belum bisa digunakan oleh masyarakat. Dimensi kualitas layanan belum diterapkan dengan baik karena dari hasil pelayanan perizinan terkadang tidak tepat waktu atau kadang melebihi ketentuan SOP, sehingga kemudahan pelayanan yang diberikan dianggap belum baik karena memerlukan proses panjang.

\section{Kinerja Staf Administrasi Bagaian Kemahasiswaan UM dalam Mewujudkan Pelayanan yang Berkualitas kepada Pengurus UKM di UM}

Penelitian terdahulu menunjukkan bahwa kinerja organisasi yang baik, akan mewujudkan pelayanan yang berkualitas pula, salah satunya adalah penelitian yang dilakukan oleh Ariany dan Putera (2013). Hal tersebut sesuai dengan hasil penelitian ini, yaitu semakin baik manajemen administrasi dan pengelolaan waktu, dan pelaksanaan berbagai kegiatan dalam rangka pelayanan kepada pengurus UKM, maka pelayanan yang berkualitas juga terwujud.

Hasil penelitian ini juga selaras dengan konsep dasar marketing pendidikan pendidikan yang dikemukakan oleh Arbangi, Dakir, dan Umiarso (2016) yakni dalam mengembangkan organisasi dilakukan pendekatan untuk memuaskan kebutuhan dan keinginan konsumen. Dalam hal ini, Bagian Kemahasiswaan UM telah melakukan pendekatan tersebut dengan cara menyelenggarakan kegiatan Workshop bagi Pengurus Ormawa UKM di UM dengan materi-materi yang diberikan sesuai dengan kebutuhan dan keinginan pengurus UKM. Selain itu, juga dipaparkan bahwa tujuan utama proses peningkatan kualitas adalah untuk meningkatkan mutu pendidikan secara berkelanjutan, terus menerus, dan terpadu. Hal tersebut juga sesuai dengan hasil penelitian ini, yakni pelayanan pegawai di Bagian Kemahasiswaan UM juga dilakukan secara terus menerus dan berkelanjutan yang mengindikasikan pada pelayanan yang baik dan berkualitas, karena pegawai Bagian Kemahasiswaan UM secara kontinyu memberikan waktu luangnya untuk melayani konsultasi pengurus UKM yang akan mengajukan proposal ataupun mengurus pencairan dana atau laporan pertanggungjawaban dana kegiatan.

\section{Faktor-faktor yang Menjadi Pendukung dan Penghambat Kinerja Staf Administrasi Bagian Kemahasiswaan Um dalam Mewujudkan Pelayanan yang Berkualitas kepada Pengurus UKM di UM}

Berdasarkan penelitian terdahulu yang dilakukan oleh Triyanto (2017) menunjukkan bahwa faktorfaktor pendukung dalam mewujudkan pelayanan yang berkulitas sudah cukup karena telah memenuhi dan menerapkan dengan baik, tiga variabel atau dimensi kinerja dan kualitas layanan yaitu produktivitas, responsibilitas, dan akuntabilitas. Apabila lima variabel tersebut semua dapat dipenuhi, maka kinerja pegawai pada suatu instansi, telah mewujudkan pelayanan yang berkualitas.

Sedangkan pada penelitian ini, lima dimensi kinerja, yakni produktivitas, responsivitas, responsibilitas, akuntabilitas, dan kualitas layanan telah terpenuhi, meskipun ada beberapa kekurangan, misalnya pada awal tahun, masih terjadi minimnya sosialisasi tentang administrasi pengajuan proposal dan laporan penggunaan dana kegiatan, kepada pengurus UKM, selain itu juga terkendalanya waktu luang pegawai untuk pelayanan konsultasi kepada mahasiswa pengurus UKM. Namun demikian, adanya hal-hal yang menjadi faktor pendukung staf administrasi Bagian Kemahasiswan UM sangatlah berpengaruh positif dalam mewujudkan pelayanan yang berkualitas kepada pengurus UKM di UM. Faktor-faktor pendukung tersebut antara lain: (1) dosen pembimbing UKM yang memiliki keahlian 
pada masing-masing bidang dalam membimbing dan membina pengurus dan anggota UKM dalam menyelenggarakan berbagai kegiatan; (2) tenaga kependidikan yang cakap dalam ilmu administrasi dan loyal dalam pelayanan; (3) tersedianya sarana dan prasarana yang baik dan memadai. UM menyediakan gedung terpadu sebagai ruang sekretariat untuk masing-masing UKM agar pengurus UKM dapat saling berkoordinasi, berinteraksi dalam membuat program kerja, menyiapkan kegiatan, dan pelaporan kegiiatan; (4) mahasiswa pengurus dan anggota UKM yang terseleksi dan mendapat prestasi pada masing-masing bidang minat dan kegemaran.

Sedangkan faktor penghambat staf administrasi bagian Kemahasiswan UM dalam mewujudkan pelayanan yang berkualitas kepada pengurus UKM di UM adalah (1) prosedur pengajuan proposal kegiatan yang panjang dan harus melalui beberapa tahap; (2) banyaknya bukti pengeluaran dana kegiatan UKM yang harus diserahkan lengkap berserta uraian laporannya dalam waktu yang terbatas; (3) tidak sesuainya waktu yang telah ditentukan dalam SOP Bagian Kemahasiswa yakni 1 (satu hari) dalam memverifikasi dan mendisposisi proposal UKM dengan kenyataan yakni diselesaikan dalam 2-3 hari; (4) banyaknya jumlah kegiatan mahasiswa di Bagian Kemahasiswaan UM dalam berbagai bidang dalam waktu yang relatif bersamaan; (5) kurangnya tenaga kependidikan yang ditugaskan di bagian Kemahasiswaan UM, hal ini tidak relevan dengan banyaknya kegiatan yang harus diselenggarakan.

Dari beberapa faktor pendukung tersebut akan menjadi kekuatan bagi UM dalam meningkatkan kualitas dan mengembangkan berbagai kegiatan dalam berbagai kegiatan bidang minat dan kegemaran. Sedangkan beberapa faktor penghambat tersebut akan menjadi bahan evaluasi dalam peningkatan kinerja dan kualitas pelayanan di Bagian Kemahasiswaan UM.

\section{SIMPULAN DAN SARAN}

\section{Kesimpulan}

Layanan staf administrasi di Bagian Kemahasiswaan UM sudah berkualitas dan pengurus UKM puas dengan pelayanan administrasi yang diberikan meskipun masih ada beberapa kekurangan di awal yakni minimnya sosialisasi tentang administrasi dan waktu untuk konsultasi. Namun hal tersebut sudah diatasi dan pelayanan administrasi dapat dilakukan dengan cepat dan tepat apabila pengurus UKM telah memahami pengajuan surat dan konten surat, prosedur pengajuan proposal kegiatan dan menyerahkan laporan dana kegiatan yang benar dan memahami pokok-pokok pelaporan dana kegiatan dan menyerahkan bukti-bukti pengeluaran anggaran dengan benar. Mahasiswa pengurus UKM merasa bahwa diselenggarakannya Workshop Kesekretariatan sangat penting dan konsultasi kepada Kasubag MPIKA dan Staf administrasi tentang proposal dan pelaporan dana yang digunakan perlu dilakukan juga merupakan hal yang diperlukan.

\section{Saran}

Workshop Kesekretriatan bagi Pengurus Ormawa UKM tetap harus dilaksanakan; sarana dan prasana di sekretariat UKM bagi pengurus UKM perlu ditambah, diperbaiki, dan ditingkatkan kualitasnya; hendaknya Kasubbag dan Staf administrasi di bagian Kemahasiswaan dapat meluangkan waktunya bagi pengurus UKM yang akan berkonsultasi sebelum melakukan kegiatan dan sebelum melaporkan buktibukti penyerapan anggaran.

\section{DAFTAR RUJUKAN}

Anggito dan Setiawan, 2018. Metodologi Penelitian Kualitatif. CV. Jejak: Sukabumi, Jawa Barat.

Ariany Ria dan Roni Ekha Putera, (2013). Analisis Kinerja Organisasi Pemerintah dalam Memberikan Pelayanan Publik di Kota Pariaman. Jurnal Mimbar, Vol. 29, No. 1, 33- 40.

Arbangi, Dakir, dan Umiarso, 2016. Manajemen Mutu Pendidikan. Cetakan I, Jakarta: PT. Adhitya Andrebina Agung, Kencana. 
Deni Triyanto, 2017. Analisis Kinerja Organisasi Dalam Mewujudkan Pelayanan Prima Kepada Masyarakat (Studi Pada Kantor Badan Perizinan Terpadu Kota Semarang). Mimbar, Jurnal Penelitian Sosial dan Politik Volume 6, No. 4.

Panduan untuk Menjadi Mahasiswa Sukses. Kepemimpinan Organisasi Mahasiswa. https://books.google.co.id/bo oks?id=ex1QDwAAQBAJ\&pg=PA97\&dq=organisasi+kemahasiswaan\&hl=id\&sa=X\&ved=2ahUKEwi2tpb rkObqAhUJU30KHS2VA84Q6AEwBXoECAQQAg diakses pada tanggal 27 Juli 2020

Panjaitan dan Yuliati, 2016. Pengaruh Kulitas Pelayanan Terhadap Kepuasan Pelanggan Pada JNE Cabang Bandung. DeReMa Jurnal Manajemen Vol. 11 Nomor 2. Program Administrasi Bisnis, Fakultas Komunikasi dan Bisnis, Universitas Telkom.

Panggabean S.,Mutiara. 2004. Manajemen SUmber Daya Manusia. Bogor. Ghalia Indonesia

Robbins, 2006. Perilaku Organisasi, PT. Indeks Kelompok Gramedia: Jakarta.

Sari, 2016. Peningkatan Kinerja Pegawai Melalui Kepuasan Kerja dan Disiplin Kerja. Jurnal Pendidikan Manajemen Perkantoran. Vol 1, No. 1.

Wididama, 2017. Analisis Pengaruh Kualitas Pelayanan Terhadap kepuasan dan Kepercayaan Pasien Rumah Sakit Umum Shanti Graha Buleleng. Jurnal Ekonomi dan Bisnis, Vol.3 No. 1 